\title{
Application of the Delphi Method to the Identification of Barriers to a Waste Management Policy in Maputo City, Mozambique
}

\author{
Leticia dos Muchangos ${ }^{1}$, Akihiro Tokai ${ }^{1} \&$ Atsuko Hanashima ${ }^{2}$ \\ ${ }^{1}$ Laboratory of Environmental Management, Division of Sustainable Energy and Environmental Engineering, \\ Graduate School of Engineering, Osaka University, Osaka, Japan \\ ${ }^{2}$ Department of Human Life and Environment, Osaka Sangyo University, Osaka, Japan \\ Correspondence: Leticia dos Muchangos, Laboratory of Environmental Management, Division of Sustainable \\ Energy and Environmental Engineering, Graduate School of Engineering, Osaka University, 2-1 Yamada-oka, \\ Suita City, Osaka Prefecture 565-0871, Japan, Tel: 81-80-3845-2105. E-mail: leticia@em.see.eng.osaka-u.ac.jp
}

\author{
Received: March 17, 2015 Accepted: May 7, 2015 Online Published: July 29, 2015 \\ doi:10.5539/jsd.v8n6p146 URL: http://dx.doi.org/10.5539/jsd.v8n6p146
}

\begin{abstract}
To correctly address the complex and challenging task of waste management, urban societies have developed and implemented waste management policies. However, authorities in developing countries are still struggling to establish waste management policies and provide acceptable waste management systems. This study examines the current Municipal Solid Waste Management (MSWM) policy in Maputo City, the capital of Mozambique, and the barriers to its implementation according to seven fundamental policy instruments: legislation and regulation; voluntary agreements; economic instruments; education and influence over behavioral change; monitoring, information and performance assessment; choice of technology; and community linkages. The Delphi method, a group problem-solving technique, was applied to collect information from experts, and 26 barriers hindering waste management policy were definitively identified.
\end{abstract}

Keywords: barriers, Delphi method, waste management policy

\section{Introduction}

There is a growing worldwide need for sustainable and coherent solutions to solid waste management (SWM) problems. SWM seems to be more complex in developing countries, where the increasing volume and a variety of wastes resulting from economic growth, urbanization, and industrialization are becoming a burgeoning problem for national and local governments that usually rely on remedial measures, uncoordinated efforts, and investment in inadequate resources making it tougher to ensure effective and sustainable waste management. The need for a good waste management plan backed by a comprehensive waste management policy, is thus indispensable because such a policy would reflect the main principles and goals of the plan (Brazilian Association of Public Cleaning and Waste Management Companies [ABRELPE] \& International Solid Waste Association [ISWA], 2013; Konteh, 2009). Planning for waste management involves three main phases: development, implementation, and review and update. Development and implementation are very crucial phases; nonetheless, because failures will occur when implementing a plan, the review and update is a necessary response to the challenge of recognizing failures, rethinking actions and turning these failures into opportunities for personal and institutional learning across the waste management. Thus, to successfully review and update a waste management plan, it is necessary to assess the progress of the existing waste management policy, including the identification of barriers to success (Hyman, Turner \& Carpintero, 2013; ABRELPE \& ISWA, 2013).

In Mozambique, authorities have acknowledged environmental matters since the early 1990s, when the National Policy for the Environment (1995) was established; since then, authorities have developed and implemented sectorial policies, including a waste management policy. However, little information exists on the status of, performance of, and barriers to this policy. In view of this, our main goal is to address the need to adequately review and upgrade current waste management planning by focusing on the identification of barriers to the waste policy in Maputo City, the capital of Mozambique, to assist policy makers and waste managers in making well-informed decisions. Firstly, providing an outline of the Municipal Solid Waste Management (MSWM) policy in place, and then, through application of a group problem-solving technique called Delphi method, to gather information from experts in waste management in Maputo City.

The remainder of this paper is structured as follows. Section 2 presents the framework of the waste management policy in Mozambique, particularly in Maputo City. An overview of waste management policy and the Delphi 
method and its application are described in Section 3. Lastly, discussion of the results from Delphi method application, followed by concluding remarks are presented respectively in Section 4 and 5 .

\section{Waste Management Policy in Mozambique}

The Mozambican Regulation on Waste Management (13/2006), defines waste as "substances or objects that are eliminated, which are intended to be eliminated or which are required by law to be eliminated". It further classifies waste as hazardous or non-hazardous. Wastes are considered hazardous if their substances bear any of the following characteristics: explosive; toxic (acute and delayed effects); infectious; corrosive; containing compressed liquefied gases or gases under pressure; flammable (liquids or solid); spontaneously combustible; capable of emitting flammable gases in contact with water; capable of releasing toxic gases in contact with air or water; comburent or oxidizing; containing organic peroxides; or eco-toxic. Conversely, non-hazardous wastes do not present any of the characteristics of hazardous waste and are classified as the following (Cabinet of ministers, 2006):

a) Domestic solid waste (or similar): generated in households or similar settings.

b) Commercial solid waste: from shops, offices, restaurants, and other similar establishments whose daily volume does not exceed 1100 liters, deposited in containers under conditions similar to domestic waste.

c) Bulky domestic waste: household waste that cannot be removed by normal means because of its volume, shape, or dimensions, whose deposition in existing containers is considered inconvenient by the municipality.

d) Garden waste: wastes from the maintenance of private gardens, such as trimmings, branches, stems, or leaves.

e) Solid waste resulting from the cleaning of public gardens, parks, roads, cemeteries, and other public spaces.

f) Industrial solid wastes: from auxiliary activities that produce similar wastes to a) and b), including that from cafeterias, canteens, and offices. Can comprise cardboard or non-contaminated substances.

g) Medical solid waste: non-contaminated waste from medical institutions; comparable to domestic waste.

h) Waste from animal defecation on the streets.

The key regulatory documents are the Environmental Law (20/97, Article 33), the Regulation on Waste Management (13/2006), the Regulation on Bio-Medical Waste Management (8/2003), the Regulation on Environmental Quality Standards and Effluent Emissions (18/2004), and the Integrated Urban Solid Waste Management Strategy for Mozambique (2012). Adding to national regulations, Mozambique also ratified to the Bamako and Basel Conventions (Ministry for Coordination of Environmental Action of Mozambique, 2008). Waste management responsibilities are divided among three authorities: the Ministry for Coordination of Environmental Action (national level), the municipalities, and the district authorities (Cabinet of ministers, 2006). Municipalities are responsible for solid waste management in urban and peri-urban areas. However, due to the limited capacity of municipal authorities to ensure service coverage, even communities that pay monthly solid waste collection fees must rely on alternative means for their relief. In most peri-urban areas, solid waste is collected from households by community-based teams and taken to a secondary disposal point. Due to the mushrooming of construction, particularly in slum areas where planning is not respected, it is impossible for waste collection vehicles to navigate the narrow streets. Municipalities in Mozambique have thus been continuously challenged to create and maintain inclusive, sustainable, and self-financing MSWM systems. This situation is illustrated in the case of Maputo City (United Nations Human Settlements Programme [UN-HABITAT], 2010).

\subsection{Case Study: The Maputo City MSWM Framework}

Maputo City (also known as The Municipality of Maputo) is the capital of and largest city in Mozambique, with approximately 1.2 million people ( $20 \%$ of the country's urban population) distributed in seven municipal districts (Stretz, 2012; UN-HABITAT, 2010).

Since 1997, the Law of the Municipalities (2/97) determined that every local authority should be responsible for managing its own urban waste in a risk-free and environmentally sound way. In Maputo City, the Municipal Council, through the Directorate of Health and Salubrity, is the appointed body responsible for managing MSW and other activities, such as cleaning public places, managing cemeteries, and developing activities for disease prevention and health promotion within the city. This authority developed the 2007 Municipal Solid Waste Management Master Plan and has been developing city by-laws and regulations (Table 1). In addition, the Directorate is not directly responsible for managing bio-medical and hazardous wastes, but it must supervise the activities to ensure that they are properly managed and report irregularities to the relevant authorities, in this case 
the Ministry for Coordination of Environmental Action and the Ministry of Health (Maputo Municipal Council, 2007).

Table 1. Maputo City MSWM regulatory framework

\begin{tabular}{|c|c|c|}
\hline Status & & Regulatory documents \\
\hline \multirow{5}{*}{ Existing } & - & $\begin{array}{l}\text { Master Plan for the Management of Municipal Solid Waste in the City of Maputo } \\
(2007)\end{array}$ \\
\hline & - & Positions for Municipal Solid Waste Cleaning in Maputo City (86/AM/2008) \\
\hline & & - $\quad$ Regulation on inspection of cleaning activities in Maputo City (87/AM/2008) \\
\hline & & $\begin{array}{l}\text { - Regulation on private sector participation in the cleaning process of Maputo } \\
\text { City }(88 / \mathrm{AM} / 2008)\end{array}$ \\
\hline & & - $\quad$ Regulation on the cleaning components of Maputo City $(89 / \mathrm{AM} / 2008)$ \\
\hline \multirow{3}{*}{ Planned } & & - $\quad$ Regulation on MSW treatment and recovery \\
\hline & & $\begin{array}{l}\text { - Regulation for sanitary landfill, treatment and transfer station operations and } \\
\text { closure of open dumps }\end{array}$ \\
\hline & & $\begin{array}{l}\text { - Regulation on information, education, and awareness of citizens of Maputo } \\
\text { Municipality cleanliness }\end{array}$ \\
\hline
\end{tabular}

\subsubsection{Economic Instruments}

The Mozambican reality defines a quite narrow window for the application of economic instruments. The main priority has been to establish sustainable MSWM systems that first address waste collection for all citizens and then ensure environmentally sound final waste disposal. Factors such as waste reduction or separation have been a lower priority over the last 10 years. In Maputo City, prominent economic instruments have been implemented for revenue generation, as described below (Stretz, 2012; Maputo Municipal Council, 2007):

- Household waste fee: A monetary contribution of waste producers to public cleansing and waste collection services; it is collected through the invoicing system of the public electrical energy provider from each household according to energy consumption levels. A fee is also charged to non-household waste producers, and it is collected in the same way as the household waste fee.

- Proof of service: All large-scale non-household waste generators with an average daily generation of more than $25 \mathrm{~kg}$ or 501 should request the services of private operators or the municipal authority itself (the Directorate of Health and Salubrity) to collect the generated waste. In addition, a fee is to be paid, charged according to daily waste generation, as a contribution to the city's general cleanliness.

- Revenues from commercial services provided by the authority.

- Disposal fee for current and future waste final disposal sites: This is charged to private operators and individuals required to register their trucks and use the weighbridge in the final disposal site entrance.

- Other fees and fines.

\subsubsection{Principles of Waste Management}

The document Positions for MSW cleaning in Maputo City, identifies two components of the Maputo City Cleaning System: general waste management activities (waste deposition at the generation point, collection and transport, storage and transfer, treatment, recovery, and final destination) and road sweeping. The underlying principles of this system are as follows:

- Principle of broad participation: MSWM is not to be undertaken exclusively by the municipal authority; rather, it should include the private sector, society in general, and each and every citizen in particular.

- Polluter Pays Principle (PPP): The polluter should restore the quality of the damaged environment and/or pay for the caused pollution.

- 3Rs principle: The system will privilege reduction, reuse, and recycling of MSW; to do so, it should gradually adopt administrative, fiscal, and legal measures as needed.

- Principle of Producer Responsibility (PR): Public or private producers are responsible for collection, transport, treatment, and final disposal.

- Principle of correction at source: MSW should be eliminated as close as possible to the generation point to avoid the economic, social, and environmental costs of its transportation.

Furthermore, six elements comprise the strategic plan to improve and increase the coverage of MSWM services 
in Maputo: institutional and organizational development of the waste sector; waste collection and transportation; waste final disposal; 3R hierarchy; education and awareness; and economic sustainability (Maputo City Municipal Assembly, 2008).

\subsubsection{Existing Problems in Maputo City MSWM System}

Despite the existence and continuing implementation of a national strategy and a local master plan, problems within the MSWM system in Maputo City still exist, and challenges have increased in recent years. A summary of these problems is presented in table 2 .

Table 2. Summary of problems relating to the objectives of MSWM in Maputo

\begin{tabular}{|c|c|}
\hline $\begin{array}{l}\text { Objectives of MSWM in Maputo } \\
\text { City }{ }^{\text {a }}\end{array}$ & Current unwanted situation \\
\hline $\begin{array}{l}\text { Strengthen the institutional and } \\
\text { organizational development of the } \\
\text { sector }\end{array}$ & $\begin{array}{l}\text { Unqualified personnel and low levels of motivation }{ }^{a} \\
\text { Problems ensuring trust between the public and private sectors }{ }^{\text {a }} \\
\text { Fragile relationship with waste scavengers }{ }^{b}\end{array}$ \\
\hline Achieve economic sustainability & Recovery cost of MSW services $-62 \%(2010)^{c}$ \\
\hline & $\begin{array}{l}\text { Increasing waste generation: } 243000 \text { ton/year in } 1995 \text { to } 600 \\
000 \text { ton/year in } 2009^{\mathrm{d}}\end{array}$ \\
\hline $\begin{array}{l}\text { Apply 3Rs } \\
-\quad \text { Potential of } 872.4 \text { tons of }\end{array}$ & Insufficient waste reuse: mostly done by low-income families $_{\mathrm{d}}^{\text {a, }}$ \\
\hline $\begin{array}{l}\text { recyclables per month in } 2003^{1} \\
-\quad \geq 50 \% \text { of organic matter in }\end{array}$ & $\begin{array}{l}\text { Limited waste recycling schemes: only done by private } \\
\text { initiatives and scavengers }{ }^{\text {a,d }} \text {. }\end{array}$ \\
\hline & $\begin{array}{l}\text { One composting scheme (processing } 3.20 \text { ton of MSW per } \\
\text { month in 2011) }\end{array}$ \\
\hline $\begin{array}{l}\text { Educate and raise awareness of the } \\
\text { population }\end{array}$ & $\begin{array}{l}\text { Low levels of public awareness and participation }{ }^{\text {a, } f} \\
\text { Public litter and misconduct }{ }^{\text {, } g} \\
\text { Population with access to regular service }-65 \%(2010)^{c}\end{array}$ \\
\hline $\begin{array}{l}\text { Attain } 100 \% \text { of MSW collection } \\
\text { and transportation coverage }\end{array}$ & $\begin{array}{l}\text { MSW collection coverage: Urban area } 90 \% \text { and Peri-urban area } \\
60 \% \mathrm{~h}\end{array}$ \\
\hline & Obsolete infrastructure and equipment ${ }^{\mathrm{a}, \mathrm{g}}$ \\
\hline $\begin{array}{l}\text { Sustainable MSW treatment and } \\
\text { final disposal }\end{array}$ & $\begin{array}{l}\text { MSW open dumping (Hulene open-dump } \geq 20 \text { years active), } \\
\text { receives } \approx 70 \% \text { of total waste generation }{ }^{\mathrm{a}, \mathrm{f}, \mathrm{g},} \\
\text { Illegal dumping }{ }^{\mathrm{a}, \mathrm{g}}\end{array}$ \\
\hline
\end{tabular}

Sources. ${ }^{a}$ Maputo Municipal Council. (2007). Master plan for municipal solid waste management in Maputo City; ${ }^{\mathrm{b}}$ Allen, C., \& Jossias, E. (2011). WIEGO organizing brief no.6 - Mapping of the policy context and catadores organizations in Maputo, Mozambique; ' Stretz, J. (2012). Concepts for Sustainable Waste Management. Economic instruments in solid waste management. Case study Maputo, Mozambique; ${ }^{\mathrm{d}}$ Ministry for Coordination of Environmental Action of Mozambique. (2012). Strategy for integrated municipal solid waste management in Mozambique; ${ }^{\text {e }}$ Buque, L. I. B. (2013). Overview of selective collection in the municipality of Maputo, Mozambique: Its contribution in municipal solid waste management, challenges and perspectives; ${ }^{\mathrm{f}} \mathrm{dos}$ Muchangos, Leticia S. (2012). A study of MSWM system in Maputo City, Mozambique - Learning experiences of Chongqing, China; ${ }^{\mathrm{g}}$ Ferrao, D. A. G. (2006). Evaluation of removal and disposal of solid waste in Maputo City, Mozambique; ${ }^{\mathrm{h}}$ Segala, K., Opressa, I., \& Palalane, J. (2008). Urbanization and municipal development in Mozambique. Chapter: Solid waste management; ${ }^{i}$ Mozambique National Cleaner Production Centre. (2007). Programme document for sustainable consumption and production in Maputo and Matola cities

\section{Methods and Materials}

\subsection{Waste Management Policy and Policy Instruments}

A clear, concise, and consistent waste management policy is necessary to establish and implement waste management systems and make necessary investments. Governments use policy instruments to achieve the objectives set out in a policy, as a result, the content and quality of existing waste policies vary widely (United Nations Environment Programme [UNEP], 2002). As noted by Vedung, in Kautto and Melanen, work (2004), no uniform and generally accepted classification of policy instruments can be found in the literature on public policy. Despite the huge range of instruments and initiatives that can be, and are, applied, some elements are centrally important to waste management policy (Hyman et al., 2013). In this study, based on the literature 
review, we selected seven instruments found to be central, comprehensive, and relevant to a standard waste management policy:

(1) Legislation and regulation: These acts oblige people and companies to do what the government tells them to do; when mandated via legislation, they motivate the target entities to achieve certain tasks or refrain from doing certain things in accordance with what is demanded in the legislation (Kautto \& Melanen, 2004; Tojo, Neubauer \& Bräuer, 2006).

(2) Voluntary agreements: Rather than requiring entities to fulfill certain tasks laid down in legislation, they can be allowed to establish their own goals and strive to achieve them via voluntary initiatives. Voluntary approaches fall into three broad categories: industries acting independently without any engagement from public authorities, negotiated agreements between public authorities and industry, and public voluntary programs designed by public authorities. The establishment of a negotiated agreement may also lead to the development of legislation (Tojo et al., 2006; Seadon, 2006).

(3) Economic instruments: These involve the remuneration or deprivation of material resources; they generally provide monetary incentives; subsidies; refunds when addressees carry out tasks the instrument wishes to promote; or disincentives, such as taxes, when addressees do not fulfill the required actions. They are used to make the system more efficient, and most importantly, internalize the costs of waste management (Tojo et al., 2006; Hyman et al., 2013).

(4) Education and influence over behavioral change: This involves influencing people through the transfer of knowledge, argumentation, or persuasion (Kautto \& Melanen, 2004; Lura Consulting, 2004)

(5) Monitoring, information, and performance assessment: Information exchange and collection is a central part of the process of policy development, choice, and implementation. It allows progress to be monitored and performance to be assessed against the goals and targets (Hyman et al., 2013).

(6) Choice of technology: This involves research on and the development of new or improved solutions and technology transfers to enable conscious and careful choices among available options (Hyman et al., 2013).

(7) Community linkages: These involve approaches or specific programs that connect solid waste solutions with other beneficial community goals and objectives, such as integrating solid waste management with socio-economic development programs (Lura Consulting, 2004).

\subsection{Methodology - Delphi Method}

The Delphi method was employed for this study. This group problem-solving technique allowed the authors to scientifically gather expert information to determine the existing barriers to the waste management policy in Maputo City. Delphi is a qualitative method developed in the 1950 s by Norman Dalkey of the RAND Corporation for a United States-sponsored military project (Skulmoski, Hartman \& Krahn, 2007). The purpose of Delphi is to facilitate a discussion that elicits a broad range of responses among selected experts in a given domain or around a particular topic (Wakefield \& Watson, 2014). In addition, as cited by Wakefield and Watson (2014), Kennedy explained, "The Delphi method provides an opportunity for experts (panelists) to communicate their opinions and knowledge anonymously about a complex problem, to see how their evaluation of the issue aligns with others, and to change their opinions, if desired, after reconsideration of the findings of the group's work".

The method is characterized by four key features: anonymity, iteration, controlled feedback, and statistical aggregation. It often begins with loosely structured, open-end questions or propositions and moves toward more quantifiable data or identifiable patterns through the combined input of the participants - but this, too, can be flexible. The goal is to move through the process until the discussion shows consensus or it becomes clear that no consensus can be reached. Respondents are asked to answer a number of questions in writing. In most cases, the answers are numeric estimates, ratings on a scale, or yes/no. Often, the respondents also have the opportunity to write comments on issues raised in the questionnaire. Statistics on answers and related comments are subsequently distributed to the respondents, but this information is anonymous, and no respondent can identify who answered what. Each respondent is allowed to modify his/her own answers and possibly add more comments. After a few rounds, some convergence in answers is normally observed due to a group opinion-building process, leading to less variance in the answers and more agreement within the panel. The number of rounds can be either predetermined or dependent on the criteria of consensus and stability. The number of respondents in Delphi panels varies from 3 to 98. Ideally, the respondents will all be experts in the same field but with somewhat different backgrounds. The final answer of the group is defined as the mean or median of the individual answers. In many cases, even the questions to be answered are proposed and selected by group members themselves before the first answering round. The forecasting accuracy of the group normally improves over Delphi rounds, and the Delphi method has been reported to work better than simple one-round surveys (Skulmoski et al., 2007; Wakefield \& Watson, 2014; Kauko \& Palmroos, 2014). 


\subsubsection{Application of the Delphi Method}

We conducted five rounds of questionnaires to collect the opinions of seven experts on sanitation and solid waste management issues in Maputo City. The group of participants included prominent professionals from academia, the public sector, non-governmental organizations, and international institutions. The demographic characteristics of the participant experts are provided in Table 3. Before beginning the Delphi rounds, a set of explanatory documents on the study objectives and the Delphi method as well as literature on waste management policy instruments were provided to each participant. The process began in April 2014 and ended in July 2014 (Figure 1).

Table 3. Demographic variables of Delphi method participants

\begin{tabular}{ll}
\hline Characteristics & Number $(\mathrm{N}=7)$ \\
\hline Gender & \\
\hline Female & 2 \\
Male & 5 \\
\hline Age & \\
\hline $31-40$ & 3 \\
$41-50$ & 3 \\
$50+$ & 1 \\
\hline Education level & \\
\hline Bachelor & 2 \\
Master & 5 \\
\hline Experience in Maputo City SWM & \\
\hline$<5$ years & 2 \\
$5-10$ & 3 \\
$11-15$ & 1 \\
$>20$ years & 1 \\
\hline
\end{tabular}

In the first round, in April 2014, the participants were asked to propose a maximum of three barriers for each of the seven waste policy instruments, resulting in 38 barriers initially proposed.

For the second round, the authors summarized these barriers and sent them back to the experts, soliciting their agreement or disagreement and comments. Upon receiving the experts' feedback from the second round, the authors listed the barriers according to the consensus status. These fell into three groups: agreed-upon barriers with/without proposed modifications, added new barriers, and non-agreed-upon barriers.

In the third round, the experts were expected to reconsider their decisions and give their opinions on the non-agreed-upon barriers and the newly added barriers and to voice their final agreement on the proposed modifications to previously agreed-upon barriers.

After receiving the third round of feedback in May 2014, the authors prepared a list of 28 consensual barriers for final evaluation and comments by the experts.

Following that, in an attempt to further trim the list of barriers, a fifth round was performed in July 2014 with three of the seven experts. The authors asked the experts to carefully review the 28 barriers and propose improvements, causing some barriers to be eliminated and others to be enhanced. As a result, a final list was produced comprising the 26 barriers identified in this process. 


\section{Preliminary work:}

Literature review on waste policy to determine relevant waste policy instruments to be included in the study

Identified prospective participants (experts) and requested contribution

Distributed explanatory material on Delphi method to willing participants

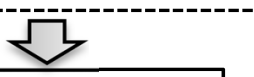

1st Round: Requested participants to list, up to three barriers for each of the seven policy instruments

\begin{tabular}{|c|c|}
\hline $\begin{array}{l}2^{\text {nd }} \text { Round: Sent the summarized list of } 38 \\
\text { barriers to obtain feedback from participants }\end{array}$ & $\begin{array}{l}\text { Consensus on } 20 \text { barriers (five } \\
\text { of them with proposed } \\
\text { amendments) } \\
\text { Disagreement on } 18 \text { barriers } \\
\text { (including justification remarks) } \\
\text { Addition of two new barriers }\end{array}$ \\
\hline $\begin{array}{l}\text { 3rd Round: Summarized the results and } \\
\text { requested participants to: validate the } \\
\text { agreed-upon barriers; re-evaluate their decisions } \\
\text { on the non-agreed-upon barriers; and evaluate } \\
\text { the new barriers. }\end{array}$ & $\begin{array}{l}22 \text { (incl. the } 02 \text { added barriers) } \\
\text { barriers confirmed } \\
\text { Consensus on } 06 \text { out of } 18 \\
\text { barriers } \\
\begin{array}{l}\text { Disagreement on } 12 \text { out of } 18 \\
\text { barriers }\end{array}\end{array}$ \\
\hline $\begin{array}{l}4^{\text {th }} \text { Round: Sent the summarized list of } 28 \\
\text { barriers to obtain feedback from participants }\end{array}$ & $\begin{array}{l}\text { Overall agreement with the list - } \\
\text { inclusion of } 28 \& \text { exclusion of } 12 \\
\text { barriers }\end{array}$ \\
\hline $\begin{array}{l}5^{\text {th }} \text { Round: Requested additional re-evaluation } \\
\text { and improvement of the } 28 \text { barriers: update, } \\
\text { check redundancies, possible combinations or } \\
\text { separations of barriers. }\end{array}$ & $\begin{array}{l}\text { Final list composed of } 26 \\
\text { barriers }\end{array}$ \\
\hline
\end{tabular}

Figure 1. Summary of the application process of Delphi method

\section{Results and Discussion}

This section aims to discuss the findings for each waste management policy instrument obtained from the application of the Delphi method by supplementing the experts' input with relevant literature on the issue.

\subsection{Legislation and Regulation}

In Maputo City, the process for establishing the MSWM regulatory framework is simultaneously in its development and implementation phases. The experts noted a gap in the effectiveness of the application and enforcement of laws and regulations caused by a lack of understanding among waste managers and law inspectors of their content and the limited resources available for enforcement activities. In addition, the experts also recognized excessive interference with legislative bodies by political bodies. These findings confirm what was previously documented by authorities in Maputo, who cited weak institutional capacity and a lack of qualified personnel as reasons for its poor SWM performance (Maputo Municipal Council, 2007). Furthermore, these results are consistent with the findings of Marshall and Farahbakhsh (2013) that reported weak institutions as being a major issue in emerging and developing countries, which means that institutional reinforcement and capacity building is a crucial requirement, and that the enforcement of laws governing regular SWM activities and new project implementation is often poor, resulting in improperly functioning SW'M systems. Regarding personnel skills, Marshall and Farahbakhsh (2013) cited Schübeler who stated that, "large discrepancies often 
exist between the job requirements and the actual qualification of the staff at the managerial and operational levels". Moreover, Chung and Lo (2008) suggested that waste management literacy among waste administrators in developing world cities, such as those in mainland China, is alarmingly inadequate. A similar situation also occurs in Mexico, as Buenrostro and Bocco (2003) reported that another consequence of poor administrative planning of public sanitation systems is that the majority of these services are directed by personnel with a low educational level and no solid waste management and/or technical training. As for the issue of political interference, Manga, Forton and Read (2008) described a representative case in Cameroon, where political interference limits efficient delivery and enforcement despite the existence of enforceable statutory instruments.

\subsection{Voluntary Agreements}

Voluntary agreements, which are often seen as a form of self-regulation, are flexible, and they foster a close dialogue among those involved (usually with wider interests, such as industry, consumer groups, NGOs, and the community). Entering into a voluntary agreement with one or more parties to introduce particular measures, is often an attractive policy option for governments. A successful example of a company's voluntary commitment is found in a case involving the well-known company $3 \mathrm{M}$, which cumulatively prevented the release of 1 metric ton of pollutants and saved US\$1 billion over 30 years. This agreement was implemented under the management of Dr. Joseph Ling, the pioneer of the Pollution Prevention Pays (PPP) program in 1975 (Hyman et al., 2013; Seadon, 2006).

In the case of Maputo City, experts understand that voluntary agreements are affected not only by the authority failing to provide an environment to foster dialogue between itself and other stakeholders, particularly the industry sector, but also by the general perception that stakeholders are exempt from active participation in waste management matters. This has led to low levels of volunteerism. The experts also referred to the stakeholders as being driven by easy profit, thus disregarding the adoption of waste management sound schemes (which is a fallacy, as demonstrated by the case of $3 \mathrm{M}$ ). In regards to stakeholders' lacking involvement, Guerrero, Maas and Hogland (2013) work on waste management in developing countries, reported that waste management is generally regarded as the sole duty and responsibility of local authorities and that the public is not expected to contribute. Also, Shekdar (2009) confirmed that societal and management apathy is among the factors responsible for poor performance in developing economies and that the operational efficiency of solid waste management depends on active participation by both municipal agencies and citizens.

\subsection{Economic Instruments}

After examining the economic instruments applied in Maputo City, the experts identified barriers that include improper budgeting processes, insufficiencies and deficiencies in the social justice of the waste fee charged to waste generators, and the absence of economic incentives to promote the 3 Rs and waste hierarchy concepts. In addition, experts also agreed that authorities and managers are not familiar with, and hence do not employ, green procurement. The lack of financial resources is an already recognized and pressing matter in Maputo City. Local authorities' projections of combined revenues for 2012, which were based on all economic instruments of the solid waste sector, only covered $69 \%$ of the costs (Stretz, 2012). To circumstantiate some of those findings, Stretz (2012) also pointed out the issue of all households connected to the public electricity grid, being obliged to pay a waste fee, regardless of their access to municipal services (if any), type of service, and frequency. Analogous conclusions can also be found in other several studies, including Marshall and Farahbakhsh (2013), Asase, Yanful, Mensah, Stanford and Amponsah (2009), Wilson, Velis and Cheesema, (2006), Sankoh and Yan (2013) and Al-Khatib, Monou, Abu Zahra, Shaheen, and Kassinos, (2010).

\subsection{Education and Influence over Behavioral Change}

The majority of identified barriers to successful education and behavioral change in Maputo City are related to badly chosen actions and a lack of political will by the authorities. Experts believe that actions to encourage waste management awareness and participation, from domestic, small generators to industrial, large generators, are lacking; those that are currently in place need to be reformulated. Experts also have noted that product import activities and internal consumption are not yet regulated to consider waste management issues. These findings align with a past assessment from Maputo's authorities, who planned to develop a public education strategy to address the recognized gap in information and communication with the public (Maputo Municipal Council, 2007). Shekdar (2009) referring to factors responsible for poor performance in developing economies, argued that because the social status of solid waste management is low, it is treated with general apathy; and that the operational efficiency of solid waste management depends on active participation of the municipal agency and of citizens. In addition, the African Ministers' Council on Water [AMCOW] et al. (2006) recognized that emerging success stories on sanitation and hygiene promotion clearly show that progress relies on political will.

\subsection{Monitoring, Information, and Performance Assessment}

In terms of planning and monitoring MMSWM activities in Maputo City, the experts acknowledged several 
issues and evaluated the current system as fostering a "pretend to work, so I pretend to pay you" environment. A lack of systematic planning and monitoring, as well as corruption and conflicts of interests, are combined with weak data availability, reliability, and information-sharing structures. The experts also believe that the authority undervalues the personnel engaged in waste removal, which is reflected in poor working conditions and the limited or non-existent capacity-building activities. This was confirmed by Guerrero et al. (2013), who examined two aspects of this matter. First, in developing countries, scant information is available in the public domain, and even this information is extremely limited, incomplete, or scattered among various agencies, making it exceptionally difficult to gain insight into MSW management. Second, waste workers suffer from low social status, which leads to low motivation. On the other hand, Marshall and Farahbakhsh (2013) noted that in low-income countries, political jostling for power means that local authorities base decision-making on the interests of their parties; thus, it is common for government bodies to maintain inflated workforces for political reasons; this consumes much-needed funds. Moreover, they stressed that petty and high-profile corruption remains a pervasive and infrequently confronted challenge for public institutions in developing countries.

\subsection{Choice of Technology}

The expert participants agreed that technology choice is constrained by the extremely limited technical capacity to carry out studies locally and to implement solutions and technologies that respond effectively to Maputo City's specific needs. Furthermore, donations and donor requirements are more often than not incompatible with the city's socio-economic situation, existing infrastructure and equipment, maintenance capacity, and local expertise. All of these barriers have been previously discussed in other works. Chung and Lo (2008) for example, stated that incompetence is found not only in the management skills of local governments (including waste authorities) in general but also in technical areas; Marshal and Farahbakhsh (2013) found that donors may be motivated by the bureaucratic procedures or goals of their home offices rather than an understanding of the local situation. Moreover, they found donor biases towards certain technical approaches or an insistence on using equipment that supports their own export industries, even though that equipment is often inappropriate for local conditions.

\subsection{Community Linkages}

In Maputo City, experts view two types of barriers to community linkages. One is the weak and non-comprehensive institutional framework for addressing this issue, including communities being underrepresented by their elected bodies (e.g., authorities and decision makers failing to integrate participatory schemes to gather public opinion, facilitate involvement, and promote transparency and accountability). The other is faulty community conduct that expects successful realization of programs without joint action with authorities or a commitment on achieving and maintaining satisfactory results. A similar issue was also cited by Chung and Lo (2008), stating that in one hand a common problem among waste authorities in developing countries is that they are weak in mobilizing the trust and cooperation of the community, and in the other hand, community support for waste management work is not entirely adequate because littering is frequent in the community, evasion of waste charges occurs frequently, and community members fail to cooperate with official waste collection hours.

\subsection{Summary of the Identified Barriers to Waste Management Policy Instruments in Maputo City}

Table 4 presents a summary of the 26 barriers to the Maputo City MSWM policy obtained through the application of the Delphi method according to seven main policy instruments.

Table 4. Barriers to the waste management policy instruments in Maputo City

Legislation and Regulation

(1) Lack of control over legal content by those responsible for its implementation

(2) Reduced law enforcement

(3) Excessive subordination of legislative power to political power

Voluntary agreements

(4) Weak framework for promoting dialogue among stakeholders

(5) General perception that the government is solely responsible for MSWM

(6) Reduced spirit of volunteerism and excessive greed for easy profits

Economic instruments

(7) Charged waste fees fail to ensure the financial sustainability of the sector and fail to reflect principles of social justice

(8) Improper budgeting and ineffective control over the costs of waste management services

(9) Lack of financial incentives to reduce waste production at its source (domestic producers), such as recycling, reuse, and other forms of exploitation 
(10) Lack of knowledge about green procurement

\begin{tabular}{l}
\hline Education and influence to behavioral change \\
(11) Weak political will \\
(12) Ineffective education programs and dissemination of good MSWM practices \\
(13) Education programs lack enforcement, supervision, and monitoring activities \\
(14) No appreciation of citizen compliance (to serve as an example) \\
(15) Too much dependence on imported products, sometimes without certification of quality \\
\hline Monitoring, information and performance assessment \\
\hline (16) Lack of planning, monitoring, and performance evaluation activities \\
(17) Unreliable information systems and databases \\
(18) Conflicts of interest and corruption \\
(19) Absence of official respect for MSWM workers and MSW handlers \\
\hline Choice of technology \\
(20)Limited directives on the objectives, capabilities, and conditions (financial, technical) of the \\
municipal authority \\
(21) Lack of knowledge about existing alternatives and their feasibility \\
(22) Dependence on donors' influence and decisions \\
(23) Insufficient maintenance of existing equipment \\
\hline Community linkages \\
(24) Reduced community sense of ownership and willingness to participate \\
(25) Lack of municipal programs in the municipal authority agenda to create and strengthen links \\
with the community \\
(26) Ineffective representation of communities in decision-making bodies
\end{tabular}

\section{Conclusion}

As authorities from urban areas have come under increased pressure to address sanitation issues successfully, particularly SWM in developing countries, policy makers and waste managers have relied primarily on the design and implementation of waste management plans. A waste management policy is the core element of a waste management plan because it reflects the plan's goals and objectives to ensure responsible, coherent, effective, and environmentally sound waste management. However, to ensure a successful waste management policy, it is important to understand its practicality and limitations. With this in mind, we studied the existing waste management policy in Maputo City and definitively identified the barriers to selected key policy instruments. The Delphi method, a group decision-making method, was used with seven experts in urban sanitation issues to acquire their knowledge and ultimately identify the barriers impeding the Maputo City MSWM system. Our conclusions are as following:

1) In Mozambique, waste management issues are recognized by the authorities and groundwork regulation and responsibilities among authorities from different jurisdiction areas are clearly defined. Maputo City as a country's representative city, is in the process of establishing, implementing and expanding a quite comprehensive waste management policy framework. However, the gap between the intended and the current waste management situation is significant, and barriers do exist within key policy instruments.

2) Following several rounds of the Delphi method application, the expert participants reached a consensus, and 26 barriers to waste management policy instruments were identified: three for legislation and regulation; three for voluntary agreements; four for economic instruments; five for education and influence over behavioral change; four for monitoring and information; four for choice of technology; and three for performance assessment and community linkages.

These findings have significant implications for policy making and managing waste because they improve the availability of information necessary to update and review the waste management plan accordingly. Nevertheless, to further enhance the decision-making process, it is important to understand the influence each barrier has on the overall MSWM system and on the other barriers. Thus, our next study will address this problem by elucidating the causal and hierarchic structure of the barriers to provide a tool for policy makers and waste managers to ensure informed decision-making and a scientifically based avoidance of unintended outcomes from waste planning.

\section{Acknowledgements}

We would like to express our gratitude to the contributors and anonymous reviewers of this paper.

We would also like to show our appreciation to each participant expert in the Delphi study, who voluntarily provided the required information in an insightful way. 
The study was completed with support from the Ministry of Education, Culture, Sports, Science, and Technology of Japan (MEXT) through its postgraduate scholarship program for foreign students.

\section{References}

African Ministers' Council on Water [AMCOW], African Development Bank, European Union Water Initiative, United Nations Development Programme [UNDP], Water and Sanitation Program-Africa [WSP-AFRICA], \& World Bank. (2006). Getting Africa on track to meet the MDGs on water and sanitation - A status overview of sixteen African countries. Nairobi.

Al-Khatib, A. I., Monou, M., Abu Zahra, A. S. F., Shaheen, H. Q., \& Kassinos, D. (2010). Solid waste characterization, quantification and management practices in developing countries. A case study: Nablus district - Palestine. Journal of Environmental Management, 91(5), 1131-1138. http://dx.doi.org/10.1016/j.jenvman.2010.01.003

Allen, C., \& Jossias, E. (2011). WIEGO organizing brief no.6 - Mapping of the policy context and catadores organizations in Maputo, Mozambique. Women in Informal Employment: Globalizing and Organizing [WIEGO].

Asase, M., Yanful, E. K., Mensah, M., Stanford, J., \& Amponsah, S. (2009). Comparison of municipal solid waste management systems in Canada and Ghana: a case study of the cities of London, Ontario, and Kumasi, Ghana. Waste Management, 29(10), 2779-2786. http://dx.doi.org/10.1016/j.wasman.2009.06.019

Brazilian Association of Public Cleaning and Waste Management Companies [ABRELPE], \& International Solid Waste Association [ISWA]. (2013). Solid waste: Guidelines for successful planning. Sao Paulo.

Buenrostro, O., \& Bocco, G. (2003). Solid waste management in municipalities in Mexico: goals and perspectives. Resources, Conservation and Recycling, 39(3), 251-263. http://dx.doi.org/10.1016/S0921-3449(03)00031-4

Buque, L. I. B. (2013). Overview of selective collection in the municipality of Maputo, Mozambique: Its contribution in municipal solid waste management, challenges and perspectives (Unpublished master's thesis). University of Sao Paulo, Sao Paulo, Brazil (in Portuguese).

Cabinet of ministers. (2006). Regulation on waste management 13/2006. Republic of Mozambique (in Portuguese).

Chung, S. S., \& Lo, C. W. H. (2008). Local waste management constraints and waste administrators in China. Waste Management, 28(2), 272-281. http://dx.doi.org/10.1016/j.wasman.2006.11.013

dos Muchangos, L. S. (2012). A study of MSWM system in Maputo City, Mozambique - Learning experiences of Chongqing, China (Unpublished master's thesis). Chongqing University, Chongqing, P.R. China.

Ferrao, D. A. G. (2006). Evaluation of removal and disposal of solid waste in Maputo City, Mozambique (Unpublished master's thesis). University of Cape Town, Cape Town, South Africa (in Portuguese).

Guerrero, L. A., Maas, G., \& Hogland, W. (2013). Solid waste management challenges for cities in developing countries. Waste Management, 33(1), 220-232. http://dx.doi.org/10.1016/j.wasman.2012.09.008

Hyman, M., Turner, B., \& Carpintero, A. (2013). Guidelines for national waste management strategies: Moving from challenges to opportunities. United Nations Environment Programme [UNEP].

Kauko, K., \& Palmroos, P. (2014). The Delphi method in forecasting financial markets-An experimental study. International Journal of Forecasting, 30(2), 313-327. http://dx.doi.org/10.1016/j.ijforecast.2013.09.007

Kautto, P., \& Melanen, M. (2004). How does industry respond to waste policy instruments - Finnish experiences. Journal of Cleaner Production, 12(1), 1-11. http://dx.doi.org/10.1016/S0959-6526(02)00023-9

Konteh, F. H. (2009).Urban sanitation and health in the developing world: Reminiscing the nineteenth century industrial nations. Health Place, 15(1), 69-78. http://dx.doi.org/10.1016/j.healthplace.2008.02.003

Lura Consulting. (2004). Solid waste as a resource - Review of waste policies. Ottawa, Ontario: Federation of Canadian municipalities [FCM]. Retrieved from https://www.fcm.ca/home.htm

Manga, V. E., Forton, O. T., \& Read, A. D. (2008). Waste management in Cameroon: A new policy perspective? Resources, Conservation and Recycling, 52(4), 592-600. http://dx.doi.org/10.1016/j.resconrec.2007.07.003

Maputo City Municipal Assembly. (2008). Positions for municipal solid waste cleaning in Maputo City 86/AM/2008. Republic of Mozambique (in Portuguese).

Maputo Municipal Council. (2007). Master plan for municipal solid waste management in Maputo City. Department of Health and Salubrity, Maputo, Mozambique (in Portuguese).

Marshall, R. E., \& Farahbakhsh, K. (2013). Systems approaches to integrated solid waste management in 
developing $\quad$ countries. $\quad$ Waste $\quad$ Management, $\quad 33(4), \quad$ 988-1003. http://dx.doi.org/10.1016/j.wasman.2012.12.023

Ministry for Coordination of Environmental Action of Mozambique. (2008). Action plan for training need, resulting from national self-evaluation. Maputo (in Portuguese).

Ministry for Coordination of Environmental Action of Mozambique. (2012). Strategy for integrated municipal solid waste management in Mozambique. Maputo (in Portuguese).

Mozambique National Cleaner Production Centre. (2007). Programme document for sustainable consumption and production in Maputo and Matola cities. Maputo.

Sankoh, F. P., \& Yan, X. (2013). Problems of solid waste management in developing urban cities: A case study of Freetown, Sierra Leone. American Journal of Environmental Protection, 2(5), 113. http://dx.doi.org/10.11648/j.ajep.20130205.11

Seadon, J. K. (2006). Integrated waste management--looking beyond the solid waste horizon. Waste Management, 26(12), 1327-1336. http://dx.doi.org/10.1016/j.wasman.2006.04.009

Segala, K., Opressa, I., \& Palalane, J. (2008). Urbanization and municipal development in Mozambique. Chapter: Solid waste management (in Portuguese).

Shekdar, A. V. (2009). Sustainable solid waste management: an integrated approach for Asian countries. Waste Management, 29(4), 1438-1448. http://dx.doi.org/10.1016/j.wasman.2008.08.025

Skulmoski, G. J., Hartman, F. T., \& Krahn, J. (2007). The Delphi method for graduate research. Journal of Information Technology Education, 6.

Stretz, J. (2012). Concepts for Sustainable Waste Management. Economic instruments in solid waste management. Case study Maputo, Mozambique. Maputo: Deutsche Gesellschaft für Internationale Zusammenarbeit [GIZ].

Tojo, N., Neubauer, A., \& Bräuer, I. (2006). Waste management policies and policy instruments in Europe - An overview. Sweeden: Lund University.

United Nations Environment Programme [UNEP]. (2002). Waste management planning: An environmentally sound approach for sustainable urban waste management. Retrieved from http://www.gdrc.org/uem/waste/waste-planning.html

United Nations Human Settlements Programme [UN-HABITAT]. (2010). Mozambique cities profile. Maputo, Nacala and Manica.

Wakefield, R., \& Watson, T. (2014). A reappraisal of Delphi 2.0 for public relations research. Public Relations Review, 40(3), 577-584. http://dx.doi.org/10.1016/j.pubrev.2013.12.004

Wilson, D. C., Velis, C., \& Cheeseman, C. (2006). Role of informal sector recycling in waste management in $\begin{array}{lllll}\text { developing } & \text { countries. } & \text { Habitat } & \text { 7nternational, } & \text { 30(4), }\end{array}$ http://dx.doi.org/10.1016/j.habitatint.2005.09.005

\section{Copyrights}

Copyright for this article is retained by the author(s), with first publication rights granted to the journal.

This is an open-access article distributed under the terms and conditions of the Creative Commons Attribution license (http://creativecommons.org/licenses/by/3.0/). 